Rev. Biol. Trop., 47(1-2): 143-149, 1999

www.ucr.ac.cr www.ots.ac.cr www.ots.duke.edu

\title{
Dry mass estimation of tropical aquatic insects using different short-term preservation methods
}

\author{
Claudia Cressa \\ Instituto de Zoología Tropical, Facultad de Ciencias, Universidad Central de Venezuela, Apartado Postal 47058, \\ Caracas 1041-A, Venezuela. Fax: 58-2-7535897. E-mail: ccressa@strix.ciens.ucv.ve
}

Received 22-I-1998. Corrected 16-X-1998. Accepted 10-XI-1998.

\begin{abstract}
Relationships of body mass and head capsule width were calculated for Thraulodes sp., Haplohyphes sp. (Ephemeroptera), Leptonema sp. and Nectopsyche sp. (Trichoptera), and Anacroneuria sp. (Plecoptera) using different preservatives (Freezing, Formaldehyde $4 \%$ and Kahle). The organisms were collected monthly during a year on the Orituco river, Venezuela with a Surber net $\left(0.1296 \mathrm{~m}^{2}\right.$ and $0.286 \mathrm{~mm}$ mesh size). The data presented here are representative of the organism conditions year around. No attempt was made to quantify intersample variation. Regression analysis indicated that all relationships were highly correlated for any of the fixatives used. Changes in dry mass per unit change of head capsule width, vary among species and preservatives with no clear relationship among them. Changes in dry mass calculated as the difference between dry mass of preserved samples to those of unpreserved ones, indicate that all fixatives underestimate dry mass by as much as $85.4 \%$, except for Nectopsyche sp. whose dry mass was always overestimated. These results provide further evidence on the effect of preservatives on dry mass losses. Even when working with tropical species, any study in which biomass is going to be determined should consider the effect of preservatives on dry mass.
\end{abstract}

Key words: Biomass, length-dry mass relationships, aquatic insects, tropics.

Dry mass, as a measure of size is a commonly used variable in a variety of macroinvertebrates population or community studies (growth rate, energy balance, secondary production, and trophic relations). Generally, since it is not possible to determine biomass immediately after collection, they are preserved for later dry mass determination (Salonen \& Sarvala 1985, Giguère et al. 1989, Cressa 1999). However, several studies indicated that fixatives produce leaching of organic matter and thus a decrease on dry mass, organic mass and/or carbon (Britt 1962,
Howmiller 1972, Dermott \& Paterson 1973, Giguère et al. 1989). In spite of these evidence, several preservation techniques are being used (freezing, combination of freezing and glutaraldehyde, buffered formaldehyde, $75 \%$ ethanol, Kahle), without a proper quantification of the error introduced on dry mass determinations.

Another approach that has been used is to measure dry mass losses due to chemical preservation by reference to wet mass of fresh specimens. This method however, is also not reliable since published estimates of dry mass 
loss, due to chemical preservation, range widely (9.0 to $63.8 \%$, Dermott \& Paterson 1973, Donald \& Paterson 1977, Heise et al. 1988, Giguère et al. 1989). On the other hand, wet weight of fresh specimens is also subject to error due to differences in water retention (Cressa 1999). Thus, a practical preservation method is urgently needed which either does not affect biomass or if it does, the changes should be known and quantified.

As mentioned above, most of the literature on dry mass losses on preserved samples analyzed the data comparing dry mass before and after some storage time in the fixative under study (Stanford 1973). However, even though the literature indicated that dry mass losses are not constant, the leaching process through time as well as the reaching of a plateau rarely is reported, leading to uncertainties on how to quantify the mass losses. Therefore, the temporal variation was controlled by keeping it constant: animals were measured and dry mass determined after a pre-established period of storage. On the other hand, since the time of preservation was kept short, two methods associated with shortterm preservation could be used: Kahle's fluid and freezing the specimens. Kahle's fluid (11\% formalin, $28 \%$ of $95 \%$ ethyl alcohol, $2 \%$ glacial acetic acid and $59 \%$ water, McCafferty 1981) has several advantages: (i) it has strong penetrative power that helps prevent breakage and dilution, (ii) it has the advantage of toughening tissues yet keeping specimens relatively soft, (iii) fixing color and (iv) body structures like legs, antennae and gills are not detached as readily as with other preservatives (Edmunds et al. 1976, McCafferty 1981). All these qualities are important on studies dealing with body dry mass determination and body measurements. Likewise, frozen samples might give an unbiased estimate of biomass and as such will eliminate the use of fixative and their undesirable effects on biomass determination (Smock 1980).

In order to quantify the effect of each preservative, dry mass losses were obtained by comparing dry mass estimates of preserved samples to that of unpreserved. Thus, the objective of this work was twofold: to determine regression equations for predicting dry mass from head capsule width for animals under different commonly used preservative (Freezing at $-5^{\circ} \mathrm{C}$, Formaldehyde $4 \%$ and Kahle) and to determine conversion factors, if needed, for the different preservatives used in this study.

\section{MATERIALS AND METHODS}

The basic data sets used for calculation were derived from a study on community structure, standing crop and secondary production of the macroinvertebrates community in the Orituco River, Venezuela (9 $\left.57-10^{\circ} 1^{\prime} \mathrm{N}, 66^{\circ} 24^{\prime}-66^{\circ} 26^{\prime} \mathrm{W}\right)$. A detailed description of the study site including the physicochemical characteristics of the river and the composition of the macroinvertebrates community are given in Cressa \& Senior (1987) and Cressa (1994).

Samples were collected monthly, during a year, with a Surber net $\left(0.1296 \mathrm{~m}^{2}\right.$ and 0.286 $\mathrm{mm}$ mesh size), separated from the debris/substrate in the field and subdivided in order to used the corresponding fixatives method. The data presented here are representative of the conditions of the organisms all year around. No attempt was made to quantify intersample variation. Animals that were going to be frozen were placed in a cooler with dry ice for its transportation to the laboratory were they were kept at $-5^{\circ} \mathrm{C}$. The day before measurements were going to be made, they were taken out of the freezer and kept at room temperature $\left(21^{\circ} \mathrm{C}\right)$ until thawing.

In the laboratory, samples were examined fifteen days after collection when larvae were cleared of attached detritus particles identified and head capsule width determined to the nearest $10 \mu \mathrm{m}$ with a stereomicroscope (Wild M5) fitted with an ocular micrometer. Head capsule width was measured as the distance across the widest portion of the head. They 
were then dried at $60^{\circ} \mathrm{C}$ during $24 \mathrm{~h}$. After cooling in a desiccator for $24 \mathrm{~h}$, they were weighed to the nearest $10 \mu \mathrm{g}$ with a Cahn electrobalance. Larvae were weighed one at the time except for the smallest size of Nectopsyche sp. and Haplohyphes sp. In these cases, animals with same head capsule width were pooled (2-3), and the mean weight determined. The data reported represents actual number of animals used for the statistical analysis (Table 1).

\section{RESULTS}

Predictive equations at the lowest determined taxonomic level for each preservative: since the power model was shown to best described the relationship of body dry mass and head capsule width for tropical aquatic insects (Cressa 1999), it was used to develop the equations for the different species for any particular preservative (Table 1). The data shown in Table 1 indicate that all regressions were highly significant $(\mathrm{p}<0.01)$. Residuals for each equation were analyzed using studentized residual plots and none of the model inadequacies were detected. This was presumed from the high values obtained for the determination coefficient $\left(\mathrm{r}^{2}\right)$ and from the high sample size used for the different treatments.

In general, change in body dry mass per unit change in head capsule width was lower for samples preserved in Kahle's fluid than for any of the other preservatives used. Furthermore, unplanned comparisons (pairwise) of regression slopes between preservatives (FreezingFormaldehyde, Freezing-Kahle, FormaldehydeKahle) for each species (GT2, p < 0.05, Sokal \& Rohlf 1981) indicate that this change was different among species as well as preservatives, without a clear relationship among the effect of preservatives on dry mass.

The analysis showed that pairwise comparisons of slopes were significantly different from each other with some exceptions. The slopes of the regression obtained from frozen samples of Leptonema sp. and Nectopsyche sp. and specimens preserved in Kahle's fluid, were not significantly different from each other. Furthermore, when slopes obtained from frozen samples of Anacroneuria sp. and Haplohyphes sp. and specimens preserved in Formaldehyde were compared, a nonsignificantly difference was obtained.

Table 1 also shows the equations relating dry mass to head capsule width for Baetis sp. and Leptohypes sp. preserved with Formaldehyde. Since data are not available for the other fixatives, they are presented only to illustrate the specificity of length - dry mass relationship as was already pointed out (Cressa 1999). Leptohypes sp. showed the highest change in dry mass per unit change of head capsule width (3.181) of all species tested in this study. This value of the slope is very similar to the expected value of 3 (LaBarbera 1989) but smaller than the one obtained for unpreserved samples of Phylloicus sp. (4.49, Cressa 1999). This result supports earlier findings regarding the importance of obtaining species-specific equations for predicting dry mass from linear body measurements. Furthermore, the data are consistent even with different preservation methods, since unplanned comparisons between slopes (GT2, p < 0.05, Sokal \& Rohlf 1981) for Leptohyphes sp. and Haplohyphes sp., which are closely related, indicate that they are significantly different.

Predictive equations at the order level for each preservative: predictive equations for each insect order from preserved samples was calculated from pooled data in that particular order (Table 1). As was the case at the species level, order-specific equations for samples preserved in Kahle showed the lowest dry mass variation with unit change of head capsule width. As before, residuals for any of the equations were analyzed using studentized residual plots and with the exception of the equation for Ephemeroptera using formaldehyde, which was the equation with the lowest $\mathrm{r}^{2}$, none of the model inadequacies were detected. 
TABLE 1

Parameters of the linear regression $\log _{10} W=\log _{10} a+b \log _{10} L$ for the relationship between head capsule width and dry mass $(\mu \mathrm{g})$ for various taxa of tropical aquatic insects using different preservation methods.

\begin{tabular}{|c|c|c|c|c|c|}
\hline Taxa & Fixative & $\log _{10} \mathrm{a} \pm \mathrm{SE}$ & $\mathrm{b} \pm \mathrm{SE}$ & $\mathrm{n}$ & $\mathrm{r}^{2}$ \\
\hline \multicolumn{6}{|l|}{ Ephemeroptera } \\
\hline \multirow{3}{*}{ Thraulodes sp. } & Freezing & $-3.711 \pm 0.178$ & $2.033 \pm 0.063$ & 64 & 0.943 \\
\hline & Formaldehyde & $-4.868 \pm 0.134$ & $2.372 \pm 0.054$ & 71 & 0.973 \\
\hline & Kahle & $-3.003 \pm 0.172$ & $1.819 \pm 0.061$ & 79 & 0.926 \\
\hline \multirow[t]{3}{*}{ Haplohyphes sp. } & Freezing & $-4.517 \pm 0.129$ & $2.311 \pm 0.048$ & 213 & 0.917 \\
\hline & Formaldehyde & $-4.020 \pm 0.120$ & $2.112 \pm 0.042$ & 101 & 0.957 \\
\hline & Kahle & $-3.385 \pm 0.125$ & $1.875 \pm 0.047$ & 223 & 0.877 \\
\hline Baetis sp. & Formaldehyde & $-2.623 \pm 0.180$ & $2.119 \pm 0.105$ & 50 & 0.892 \\
\hline Leptohyphes sp. & Formaldehyde & $-6.455 \pm 0.154$ & $3.181 \pm 0.058$ & 52 & 0.983 \\
\hline \multirow[t]{4}{*}{ Ephemeroptera General } & Freezing & $-4.318 \pm 0.107$ & $2.240 \pm 0.039$ & 277 & 0.922 \\
\hline & Formaldehyde & $-1.321 \pm 0.126$ & $1.163 \pm 0.049$ & 274 & 0.673 \\
\hline & Formaldehyde* & $-4.387 \pm 0.105$ & $2.228 \pm 0.038$ & 172 & 0.952 \\
\hline & Kahle & $-3.513 \pm 0.111$ & $1.945 \pm 0.041$ & 302 & 0.881 \\
\hline \multicolumn{6}{|l|}{ Trichoptera } \\
\hline \multirow[t]{3}{*}{ Leptonema sp. } & Freezing & $-5.256 \pm 0.134$ & $2.811 \pm 0.047$ & 117 & 0.970 \\
\hline & Formaldehyde & $-4.482 \pm 0.115$ & $2.474 \pm 0.041$ & 195 & 0.950 \\
\hline & Kahle & $-3.801 \pm 0.211$ & $2.270 \pm 0.075$ & 169 & 0.845 \\
\hline \multirow[t]{3}{*}{ Nectopsyche sp. } & Freezing & $-2.312 \pm 0.062$ & $1.771 \pm 0.027$ & 68 & 0.985 \\
\hline & Formaldehyde & $-3.334 \pm 0.221$ & $2.208 \pm 0.091$ & 58 & 0.912 \\
\hline & Kahle & $-3.225 \pm 0.135$ & $2.102 \pm 0.054$ & 107 & 0.935 \\
\hline \multirow[t]{3}{*}{ Trichoptera General } & Freezing & $-3.014 \pm 0.10$ & $2.044 \pm 0.037$ & 185 & 0.943 \\
\hline & Formaldehyde & $-2.726 \pm 0.127$ & $1.875 \pm 0.046$ & 253 & 0.866 \\
\hline & Kahle & $-3.149 \pm 0.115$ & $2.050 \pm 0.043$ & 276 & 0.893 \\
\hline \multicolumn{6}{|l|}{ Plecoptera } \\
\hline \multirow[t]{3}{*}{ Anacroneuria sp. } & Freezing & $-6.286 \pm 0.258$ & $2.933 \pm 0.081$ & 64 & 0.954 \\
\hline & Formaldehyde & $-6.281 \pm 0.382$ & $2.924 \pm 0.127$ & 57 & 0.904 \\
\hline & Kahle & $-4.753 \pm 0.164$ & $2.449 \pm 0.053$ & 123 & 0.945 \\
\hline
\end{tabular}

* Baetis sp. and Leptohyphes sp. not included

$\mathrm{a}, \mathrm{b}=$ regression constants, $\mathrm{SE}=$ standard error of the estimate, $\mathrm{r}^{2}=$ determination coefficient .

Unplanned comparison of regression slopes between fixatives for each order (GT2, p $<0.05$, Sokal \& Rohlf 1981) indicated that for Trichoptera the slopes were non-significantly different among preservatives (FreezingFormaldehyde, Freezing-Kahle, FormaldehydeKahle), while for Ephemeroptera slopes were non-significantly different only when comparisons were made between Freezing and Formaldehyde. Furthermore, comparisons of slopes among orders from samples using the same preservation method were all significantly different, indicating that changes in dry mass per unit change of head capsule width differ significantly at this taxonomic level. 
Comparisons of weight estimates between preserved and unpreserved samples for each species: the relationship relating head capsule width to dry mass for each species for a given preservative (Table 1) was used to compare predicted dry mass (Table 2). In order to make meaningful comparisons for each species, the mean of the range of head capsule widths was used in the calculations. Table 2, also shows the difference in dry mass estimates (as a percentage) obtained between preserved and unpreserved samples. The relationship relating head capsule width to dry mass for each species for

TABLE 2

Predicted dry mass of individuals organisms ( $W, \mu g$ dry) calculated from the species-specific preservative equations given in Table 1.

\begin{tabular}{|c|c|c|c|c|c|c|}
\hline Taxon & Fixative & $\begin{array}{c}\text { Head capsule } \\
\text { width }(\mu \mathrm{m})\end{array}$ & $\begin{array}{c}\mathrm{W} \\
(\mu \mathrm{g})\end{array}$ & $\begin{array}{c}95 \% \mathrm{CI}^{*} \\
(\mu \mathrm{g})\end{array}$ & $\begin{array}{c}\text { \%Difference } \\
\text { underestimation }\end{array}$ & $\begin{array}{c}\% \text { Difference } \\
\text { overestimation }\end{array}$ \\
\hline \multicolumn{7}{|c|}{ Thraulodes sp. } \\
\hline & Freezing & 888 & 191.93 & $175.36-210.06$ & 79.55 & \\
\hline & Formaldehyde & & 135.45 & $126.15-145.44$ & 85.56 & \\
\hline & Kahle & & 228.63 & $210.26-248.61$ & 75.66 & \\
\hline & No-Fixative & & 938.33 & $874.58-1006.72$ & & \\
\hline \multicolumn{7}{|c|}{ Haplohyphes sp. } \\
\hline & Freezing & 337 & 21.16 & $19.65-22.78$ & 85.17 & \\
\hline & Formaldehyde & & 20.76 & $19.45-22.16$ & 85.45 & \\
\hline & Kahle & & 22.70 & $20.95-24.59$ & 84.09 & \\
\hline & No-Fixative & & 142.71 & $134.47-151.47$ & & \\
\hline \multicolumn{7}{|c|}{ Leptonema sp. } \\
\hline & Freezing & 1480 & 4529.11 & $4206.65-4876.29$ & 30.87 & \\
\hline & Formaldehyde & & 2297.89 & $2154.08-2451.30$ & 64.94 & \\
\hline & Kahle & & 2491.76 & $2187.98-2837.71$ & 61.96 & \\
\hline & No-Fixative & & 6551.22 & $5751.86-7461.66$ & & \\
\hline \multicolumn{7}{|c|}{ Nectopsyche sp. } \\
\hline & Freezing & 325 & 136.76 & $130.90-142.89$ & & 23.47 \\
\hline & Formaldehyde & & 163.33 & $148.75-179.34$ & & 47.42 \\
\hline & Kahle & & 113.55 & $108.01-119.37$ & & 2.49 \\
\hline & No-Fixative & & 110.79 & $105.87-115.94$ & & \\
\hline \multicolumn{7}{|c|}{ Anacroneuria sp. } \\
\hline & Freezing & 2000 & 2311.45 & $2130.28-2508.04$ & & 53.91 \\
\hline & Formaldehyde & & 2346.75 & $1936.71-2843.56$ & & 53.21 \\
\hline & Kahle & & 2143.50 & $1919.68-2393.42$ & & 57.26 \\
\hline & No-Fixative & & 5015.07 & $4479.47-5614.71$ & & \\
\hline
\end{tabular}

The dry mass overestimation or underestimation was calculated as the difference (in percentage) between preserved samples to that of unpreserved samples (No-fixative).

${ }^{*} \mathrm{CI}=$ Confidence intervals 
unpreserved samples are those given in C Cressa (1999). In general, all methods of preservation underestimated weight (30.9 - 85 . $6 \%$ ), with losses higher than those published for temperate aquatic insects (Dermott \& Paterson 1973, Heise et al. 1988).

Leptonema sp. and Anacroneuria sp. showed the same order of magnitude of underestimation $(30.9 \%$ - 57.3\%) of weight, while the two species of Ephemeroptera presented the highest difference $(79.7 \%$ $85.5 \%)$. On the other hand, Nectopsyche sp. was the only species showing an overestimation of weight for any of the preservatives used. Furthermore, this species also showed the highest difference in weight estimates $(2.5 \%$ $47.4 \%$ ). Table 2 also indicates that the range of the difference on weight estimates is higher for the two species of Trichoptera than for Ephemeroptera or Plecoptera (Table 2).

\section{DISCUSSION}

The high correlation of the relationship between body weight and head capsule width (Table 1) obtained for all species, regardless of the fixative used, indicated that losses on weight due to preservation could not be disregarded, particularly, when the data are intended to be used for production/biomass estimates. Furthermore, this study shows that even though losses of weight in animals frozen were smaller than when using Formaldehyde as a fixative, they are of such magnitude that the freezing process could not be considered as not affecting weight determination. It is necessary to mention that the relationships presented by Smock (1980) are for frozen samples and not fresh ones (unpreserved). Therefore, the effect of freezing on mass losses has rarely been tested.

The lack of a clear relationship between dry mass difference among preservatives for the different species could be an indication that leaching is dependent on the dimensions and physiological conditions (age, sex, nutrition stage, Giguère et al. 1989) of the organisms. It is noteworthy to mention that Nectopsyche sp. is the only species where the animal together with its case were subject to the different preservatives, since animals were separated of their cases only after they were subject to a particular treatment. Therefore leaching in this species could be affected by the case. Nevertheless, the overestimation of dry mass when comparing preserved samples to unpreserved ones is difficult to explain, unless a chemical reaction between fixatives-caseorganisms do happen (precipitation) that will increase dry mass. However, there are not enough data available to test this hypothesis and it should be interesting to establish length-dry mass relationships with other species of Trichoptera that have to be preserved with their cases, in order to make meaningful comparisons.

Studies where dry mass losses were related to preservation time (Howmiller 1972, Stanford 1973) indicated that dry mass tend to stabilize after 25 days. Since in this study weight losses were already high after fifteen days, it looks like that these differences could be considered as the maximum for any of the preservatives used. However, the temporal variation on the effects on weight determinations on specimens kept during longer period of time has to be tested.

Two ways for calculating predicted dry mass could be used under the conditions presented in this study: (i) using the regression equations for each species for preserved samples (Table 1) or (ii) using the percentage of dry mass losses obtained when comparing dry mass of preserved samples to that of unpreserved ones (Table 2).

Since there are no data available for tropical aquatic insects to allow some comparisons with those presented here, I recommend to determine length-dry mass relationships in animals not preserved whenever possible. Furthermore, I recommend using specific equations at the lowest possible taxonomic level, in view of the data obtained for any of the fixatives used. The fact that the studentized residuals obtained with Ephemeroptera preserved with formaldehyde, indicated that the general equations does not comply with the assumptions of the power 
equations while at the species level it does, clearly illustrated this statement.

\section{ACKNOWLEDGMENTS}

This study has been supported by the Consejo de Desarrollo Científico y Humanístico of the Universidad Central de Venezuela (Grant No. C03-10-2280/90). I thank Pedro Hernández Gil for allowing access to his private land, Brunilda Heredia, Director of the Guanapito Experimental Station (FONAIAP), for her logistic support and the Institute of National Parks for allowing use of its facilities. The comments of Peter Burgherr on an earlier version of the manuscript are greatly appreciated as well as the advised of Luis Bulla on statistical procedures.

\section{RESUMEN}

Se calcularon las ecuaciones para las relaciones entre la masa del cuerpo y el ancho de la cápsula cefálica para Thraulodes sp., Haplohyphes sp. (Ephemeroptera), Leptonema sp., Nectopsyche sp. (Trichoptera) y Anacroneuria sp. (Plecoptera) usando diferentes preservativos (Congelamiento, Formol $4 \%$ and Kahle). El análisis de regresión indicó que todas las relaciones obtenidas son altamente significativas para cada uno de los preservativos utilizados. Los cambios en la masa del cuerpo por unidad de cambio en el ancho de la cápsula cefálica, son diferentes para cada especie y preservativo, sin haberse obtenido una clara relación entre ellos. La compararación entre los valores de masa obtenidos con los diferentes preservativos y los obtenidos con muestras no preservadas, indica que todos los preservativos subestiman la masa seca hasta en un 85,4\%, excepto en el caso de Nectopsyche sp. cuya masa corporal fue siempre sobre-estimada. Los resultados presentados en este trabajo nuevamente indican, aún trabajando con insectos acuáticos tropicales, que cualquier estudio en el cual la biomasa va a ser determinada, debe de tener en cuenta el efecto que los preservativos producen en la disminución de la masa corporal.

\section{REFERENCES}

Britt, N. W. 1962. Biology of two species of Lake Erie mayflies, Ephoron album (Say) and Ephemera simulans Walker. Bull. Ohio. Surv. 1: 1-70.

Cressa, C. 1999. Dry weight estimates of some tropical aquatic insects. Rev. Biol. Trop. 47:129-140.
Cressa, C. 1994. Structural changes of the macroinvertebrate community in a tropical river. Verh. Internat. Verein. Limnol. 25: 1853-1855.

Cressa, C. 1986. Estimaciones de peso seco en función de la longitud cefálica y clases de tamaño en Campsurus sp. (Ephemeroptera, Polymitarcidae). Acta Cient. Venez. 37: 170-173.

Cressa, C. \& C.T. Senior. 1987. Aspects of the chemistry and hydrology of the Orituco river, Venezuela. Acta Cient. Venez. 38: 99-105.

Edmunds, G.F., Jr., S.L. Jensen \& L. Berner. 1976. The mayflies of North and Central America. University of Minnesota, Minneapolis.

Dermott, R. M. \& C. G. Paterson. 1973. Determining dry weight and percentage dry matter of chironomid larvae. Can. J. Zool. 52: 1243-1250.

Donald, G. L. \& C. G. Paterson. 1977. Effect of preservation on wet weight biomass of chironomid larvae. Hydrobiologia 53: 75- 80.

Giguère, L. A., J. F. St-Pierre, B. Bernier, A. Vezina, \& J. G. Rondeau. 1989. Can we estimate the true weight of zooplankton samples after chemical preservation? Can. Fish. Aquat. Sci. 46: 522-527.

Heise, B. A., J. F. Flannagan \& D. Galloway. 1988. Production of Hexagenia limbata (Serville) and Ephemera simulans Walker (Ephemeroptera) in Dauphin Lake, Manitoba, with a note on weight due to preservatives. Can. J. Fish. Aquat. Sci. 45: 774-781.

Howmiller, R. P. 1972. Effect of preservatives on weights of some common macrobenthic invertebrates. Trans. Am. Fish Soc. 101: 743-746.

La Barbera, M. 1989. Analyzing body size as a factor in ecology and evolution. Annu. Rev. Ecol. Syst. 20: 97-117.

McCafferty, W.P. 1981. Aquatic Entomology. The Fishermen's and Ecologist's Illustrated Guide to Insects and Their Relatives. Science Books International, Boston, Massachusetts.

Salonen, K. \& J. Sarvala. 1985. The effect of different preservation methods on the carbon content of Megacyclops gigas. Hydrobiologia 72: 281-285.

Sokal, R. R. \& F.J. Rohlf. 1981. Biometry. J.W.H. Freeman, San Francisco, California.

Stanford, J. A. 1973. A centrifuge method for determining live weights of aquatic insect larvae, with a note on weight loss in preservative. Ecology 54: 449-451. 